UDC: 582.32 .575 .17

\title{
ROLE OF THE BRYOPHYTE COVER IN ACCUMULATION OF ORGANIC CARBON AND BIOGENIC ELEMENTS IN TECHNOGENIC SUBSTRATE ON THE TERRITORY OF SULFUR DEPOSIT
}

\author{
N. Ya. Kyyak, O. L. Baik \\ Institute of Ecology of the Carpathians, NAS of Ukraine, 11, Stefanyk St., Lviv 79000, Ukraine \\ e-mail:kyyak_n@i.ua
}

The influence of bryophyte cover on accumulation of organic carbon and biogenic elements in substrate of the dump No1 of Yazivsky sulphur deposit of State MiningChemical Enterprise "Sirka" was investigated. The bryophytes were among the first to settle on the dump substrates and form thick, multispecific overgrowth. It was showed, that quantity of the organic carbon in the substrate under moss turfs has increased 1.6-1.8 times compared to its content in substrate without the turfs. The lowest indices of the organic carbon content was detected on the dump top that might be caused by a tension of the ecological factors on this plot (high insolation level, moisture deficit). It was established that bryophytes promote enriching dump substrate with the biogenic elements, first of all, nitrogen and phosphorus. High variability of the organic substance content was determined by both specific moss peculiarities and the microconditions on the dump territory. Life form of species is of great importance, as the highest indices of the organic carbon, nitrogen and phosphorus content was established under moss cover, formed by dense turf species Bryum caespiticium. Thus, the bryophytes as pioneer plants play an important role in process of the renewal of technogenic substrates, promoting accumulation of the organic substance, and in this way creating the conditions for the development of other higher plants and soil biota.

Keywords: bryophytes, organic carbon, biogenic elements, dump of sulphur deposits.

\section{INTRODUCTION}

The problem of termination of technogenic degradation of soils and its phytomelioration has got a global importance and requires an urgent decision. It concerns also the Western region of Ukraine where during several decades the extraction of sulfur, sand and clay occurs by the open way. The process of formation and development of plants cover and ecosystems in the technogenic landscapes occurs as a primary succession.

It was established that in Poland on the posttechnogenic areas of sulfur and nitrogen extraction on the initial stages of plant succession the ruderal species with high resistance to the anthropogenic stress were dominant. For example, within the impact zone

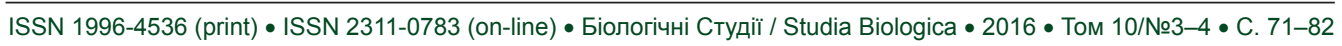


of "Osiek" Sulphur Mine the pioneer plants species were Cineraria farfara Bernh., Polygonum aviculare L. and Calamagrostis epigeios (L.) Roth. On the later stages of succession Leontodon hispidus L., Lolium perenne L., Trifolium repens L., Taraxacum vulgare (Lam.) Schrank, Festuca rubra L. and Poa compressa L. were found. These plants had an important influence on the restoration of substrates of the devastated areas [18; 19].

In our primary investigation, it was shown that overgrowing of tertiary marly clays, quaternary loams and sandy deposit occurs by the consecutive stages of development of bryophyte communities, differing by specific structure, structural and functional organization.

A new approach connected with maximum utilization of the regenerating possibilities of natural ecosystems for restoring resources and ecological functions of devastated territories - their "ecological restoration" has been formed in world practice of the technogenic geosystems rehabilitation. The use of potential of plants communities, adapted to antropogenically changed substrates gives a chance to decrease intensity of denudation processes of technical earth to great extent and initiate soil forming processes there. The conception of technogenic geosystems renaturalization is ecologically grounded and economically justifies [7].

As a result of open-cast mine exploitation of native sulphur extraction on the territory of Novoyavorivsk State Mining-Chemical Enterprise "Sirka" (L'viv region, Ukraine), a number of various age dumps formed both from the rocks which take part in zone soil formation and from bedding rocks which do not form soils (e.g. tertiary clays, sulphur containing limestones etc.) have been formed. The main problem in cultivating dump rocks is its alienation for biota and sometimes its toxicity. The population of rock substrates by the microorganisms and pioneer plants promotes structuring of such substrates qualitative and quantitative changes of properties which identify the formation of young technogenic soils.

The bryophytes were among the first to settle on the dump substrates and formed thick, multispecific overgrowth (Fig. 1) [14].

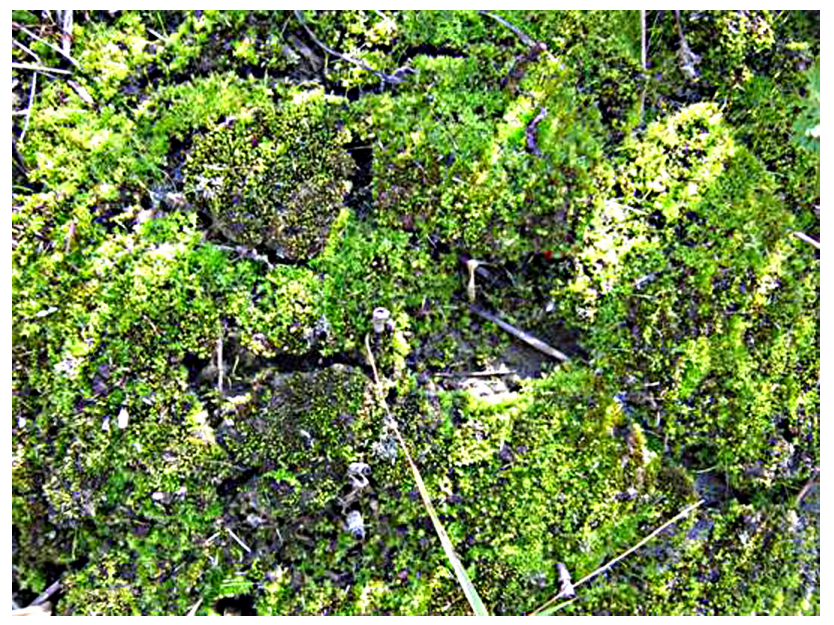

Fig. 1. Moss cover formed by Bryum caespiticium Hedw. and Barbula unguiculata Hedw. on the dump crest

Рис. 1. Моховий покрив, сорормований Bryum caespiticium Hedw. та Barbula unguiculata Hedw. на гребені відвалу

Gradually dying off, the pioneer bryophyte species create the substrate for populating other mosses and vascular plants. The way in which bryophytes change technogenic substrate has not been investigated enough. It is known from literature that moss

ISSN 1996-4536 (print) • ISSN 2311-0783 (on-line) • Біологічні Студії / Studia Biologica • 2016 • Том 10/№3-4 • С. 71-82 
cover essentially influences both the soil formation processes and the ecological conditions inside the ecosystem: hydrothermal conditions in rhizosphere, soil acidity, mineral regime, deposition and carbon cycle [5; 11; 15].

However, a question of the mosses role in revitalization of technogenic soils and on the territories of sulphur extraction remains poorly investigated. The aim of this work was to investigate the influence of bryophyte cover on the accumulation of organic carbon and biogenic elements in the dump No1 substrate of Yazivsky sulphur deposit of State Mining-Chemical Enterprise "Sirka".

\section{MATERIALS AND METHODS}

The object of investigation was bryophytes from the dump No 1 of Yazivsky sulphur deposit (L'viv region, Yavoriv district), belonging to Novoyavorivsk sulphur deposit of State Mining-Chemical Enterprise „Sirka”. For investigations 3 moss species were chosen: Barbula unguiculata Hedw., Bryum argenteum L. and Bryum caespiticium Hedw. For investigation of bryophytes influence on accumulation of biogenic elements in the dump substrate, the substrate samples under moss cover have been chosen for experiments and the surface substrate layer of $2-3 \mathrm{~cm}$ wide where the bryophyte cover is of the greatest influence, has been analyzed [20]. The samples of the base substrate (without plant cover) have been used as control. The investigations have been carried out on 7 investigated dump transects (the dump crest and 6 transects on the northern and southern slopes) in summer and autumn of 2013-2015. The substrate has been chosen in 3 places within experimental plot; the average sample has been mixed and formed.

Determination of the organic carbon content in the substrate was fulfilled by I. V. Turyn method in modification of B. A. Nikityn [10], that is based on oxidation of the organic substance by chromium mixture in strongly acidic medium. The optical density of solutions was measured spectrophotometrically on the Specord 210 Plus device having the wave length $590 \mathrm{~nm}$ and was expressed in percentage.

The content of total nitrogen in the substrate was determined by K'endal' method [1], the phosphorus content was determined photocolorimetrically measuring intensity of phosphorus-molybdenum blue color, the potassium content was determined by the photometer PFM-BP-3OM3 [2].

All experiments were repeated three times. The obtained results were processed by the methods of statistical analysis [13].

\section{RESULTS}

Most scientists who investigated the processes of young soil formation on the territories devastated by extraction of natural deposits point to the rapid accumulation rates of organic substance in posttechnogenic soils [7]. The process is closely connected with the constant over-growth of plant cover productivity, namely the increase of plant fall quantity. The pioneers of bryophyte species which were used in investigations settling on the dump slopes cause both mechanical and chemical influence on the substrate. First of all, they fix the movable slopes of substrate mechanically and prevent it from scattering light fractions. The species that form the life form of dense turf Bryum caespiticium plays a special part in these processes. Besides, the species Bryum caespiticium forms dense rhizoid tomentum which penetrates into substrate densely providing plants with additional fixation on the slopes. It has been found out

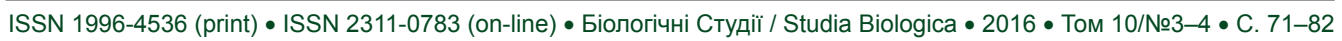


during investigations that in some turfs Bryum caespiticium rhizoid tomentum reached $3 \mathrm{~cm}$. Penetrating into the substrate moss rhizoids form dense net, increasing porosity and promoting enrichment of substrate with oxygen and moisture. On the basis of substrates analysis, on which moss turfs overgrow it has been found out that under moss cover formed by dense turf species Bryum caespiticium a clear interlayer of dark color embryonic organic accumulative horizon made by the products of dying off turf has been formed (Fig. 2). This interlayer is smaller under loose turfs Barbula unguiculata or Bryum argenteum especially on the slopes as turfs of these species are destroyed easily as the result of displacement of unstable substrate and hold the occupied area uneffectively compared to Bryum caespiticium. It has been noted that the thickness of bedding under moss turfs depends to great extent both on the specific properties and on the growth locality of plants on the dump slopes with rather complex climatic conditions. For example, in summer months substrate humidity on the crest and the north dump slope amounted to $26.3-27.5 \%$, the light intensity was $6.5-8.5$ thousand lux, the temperature on the substrate surface was $+18.4-+25.2{ }^{\circ} \mathrm{C}$. The top and the south dump slope are characterized by the least favorable conditions (substrate humidity 4.5-14.8\%, light intensity was $10.0-11.0$ thousand lux, the temperature on the substrate surface has increased to $+35.2-+40.2{ }^{\circ} \mathrm{C}$.

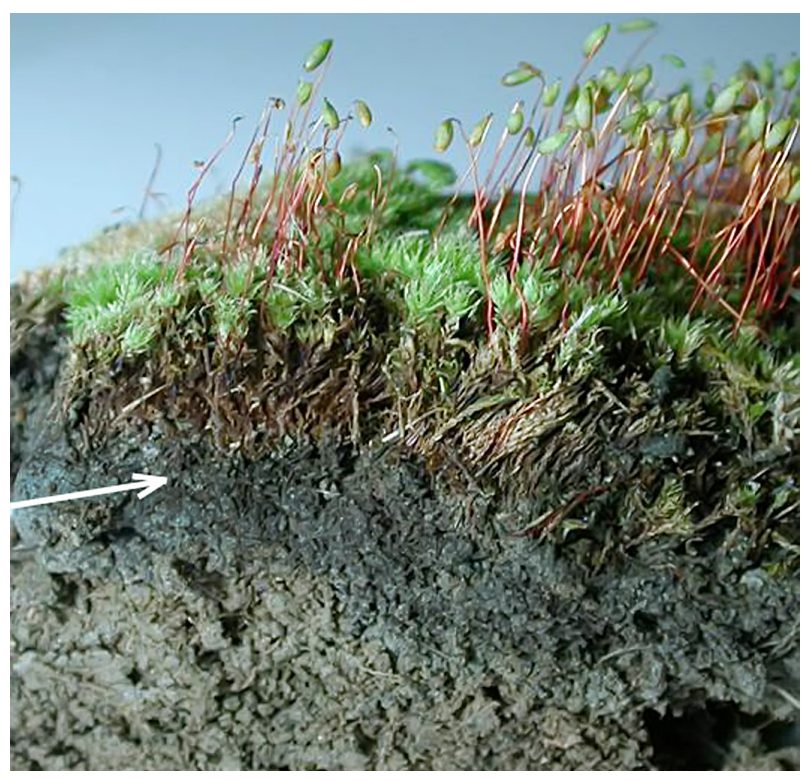

Fig. 2. The formation of organo-accumulative horizons under moss turfs Bryum caespiticium Hedw.

Рис. 2. Формування органо-акумулятивного горизонту під дернинами моху Bryum caespiticium Hedw.

The ability of dump rocks to form fertile soil by $25-30 \%$ depends on the presence of the organic carbon. Taking into account this fact, the substrate containing $0.5-1.0 \%$ of organic carbon is considered to be the substrate of fertile soil layer $[7 ; 8]$. The process of technogenic lands overgrowing takes place in such a substrate that provides the corresponding level of stable soil ecological functions creates natural preconditions for the development of soil cover on the devastated territories.

Content of the organic carbon in the upper layer of the bare substrate (without plant cover) was $0.9-1.9 \%$ in the territory of dump No 1 (Table 1). Besides, a tendency to

ISSN 1996-4536 (print) • ISSN 2311-0783 (on-line) • Біологічні Студії / Studia Biologica • 2016 • Том 10/№3-4 • С. 71-82 
content decrease of the organic carbon from the dump base to the top by 1.5-2.0 times has been found out. First of all, this is caused by the conditions peculiarities on the dump top, which are the least favourable for plants growth as a result of wind and water substrate erosions, as well as moisture deficit that leads to slowing down renaturalization processes of rock substrates. Such difference in quantity of the organic carbon on the dump top can be caused by washing out the surface substrate layer from the top to the dump base.

Table. 1. Content of the organic carbon in the substrate under moss cover on the territory of the dump No 1 (2013-2015)

Таблиця 1. Вміст органічного карбону у субстраті під моховим покривом на території відвалу №1 (2013-2015р.)

\begin{tabular}{|c|c|c|c|c|}
\hline \multirow{3}{*}{$\begin{array}{l}\text { Locality of substrate } \\
\text { samples collection under } \\
\text { moss turfs }\end{array}$} & \multicolumn{4}{|c|}{ Content of organic carbon, \% } \\
\hline & \multicolumn{2}{|c|}{ North slope } & \multicolumn{2}{|c|}{ South slope } \\
\hline & 2013 y. & 2015 y. & 2013 y. & 2015 y. \\
\hline \multicolumn{5}{|c|}{ Uncovered substrate (control) } \\
\hline Crest of the dump & $1.75 \pm 0.07$ & $1.79 \pm 0.09$ & & \\
\hline Base & $1.71 \pm 0.09$ & $1.78 \pm 0.10$ & $1.84 \pm 0.25$ & $1.89 \pm 0.08$ \\
\hline Slope & $1.59 \pm 0.10$ & $1.60 \pm 0.10$ & $1.65 \pm 0.14$ & $1.68 \pm 0.11$ \\
\hline Top & $1.19 \pm 0.20$ & $1.22 \pm 0.15$ & $0.92 \pm 0.24$ & $0.96 \pm 0.12$ \\
\hline \multicolumn{5}{|c|}{ Bryum caespiticium } \\
\hline Crest of the dump & $4.75 \pm 0.06^{*}$ & $4.97 \pm 0.08^{*}$ & & \\
\hline Base & $2.70 \pm 0.04^{*}$ & $2.94 \pm 0.09^{*}$ & $2.45 \pm 0.21^{*}$ & $2.57 \pm 0.07^{*}$ \\
\hline Slope & $2.95 \pm 0.04^{*}$ & $3.10 \pm 0.11^{*}$ & $2.48 \pm 0.16^{*}$ & $2.75 \pm 0.06^{*}$ \\
\hline Top & $2.41 \pm 0.08^{*}$ & $2.52 \pm 0.09^{*}$ & $2.11 \pm 0.10^{*}$ & $2.23 \pm 0.08^{*}$ \\
\hline \multicolumn{5}{|c|}{ Bryum argenteum } \\
\hline Crest of the dump & $4.16 \pm 0.07^{*}$ & $4.37 \pm 0.06^{*}$ & & \\
\hline Base & $2.75 \pm 0.07^{*}$ & $2.86 \pm 0.07^{*}$ & $2.05 \pm 0.09^{*}$ & $2.16 \pm 0.15^{*}$ \\
\hline Slope & $2.93 \pm 0.06^{*}$ & $3.06 \pm 0.08^{*}$ & $2.52 \pm 0.11^{*}$ & $2.61 \pm 0.12^{*}$ \\
\hline Top & $2.23 \pm 0.10^{*}$ & $2.33 \pm 0.11^{*}$ & $2.16 \pm 0.09^{*}$ & $2.22 \pm 0.14^{*}$ \\
\hline \multicolumn{5}{|c|}{ Barbula unguiculata } \\
\hline Crest of the dump & $3.36 \pm 0.31^{*}$ & $3.46 \pm 0.09^{*}$ & & \\
\hline Base & $2.22 \pm 0.09^{*}$ & $2.29 \pm 0.22^{*}$ & $2.13 \pm 0.11^{*}$ & $2.26 \pm 0.08^{*}$ \\
\hline Slope & $2.31 \pm 0.10^{*}$ & $2.39 \pm 0.11^{*}$ & $2.10 \pm 0.10^{*}$ & $2.18 \pm 0.07^{*}$ \\
\hline Top & $2.01 \pm 0.10^{*}$ & $2.07 \pm 0.09^{*}$ & $1.56 \pm 0.09^{*}$ & $1.63 \pm 0.09^{*}$ \\
\hline \multirow{2}{*}{\multicolumn{5}{|c|}{$\begin{array}{l}\text { * - difference compared to control (base substrate) is statistically reliable at } p<0.05 \\
\text { * - різниця порівняно } 3 \text { контролем (оголений субстрат) статистично достовірна при р <0,05 }\end{array}$}} \\
\hline Примітка: * - різниця порівн & & & & \\
\hline
\end{tabular}

ISSN 1996-4536 (print) • ISSN 2311-0783 (on-line) • Біологічні Студії / Studia Biologica • 2016 • Том 10/№3-4 • С. 71-82 
$\mathrm{C}_{\text {org. }}$ content is to $16.3 \pm 1.5 \%$ in the dead shoot parts in Bryum caespiticium, in Bryum argenteum it is $14.5 \pm 1.3 \%$ and $12.5 \pm 1.2 \%$ in Barbula unguiculata. Quantity of the organic carbon is 3-4 times smaller in green shoot parts of these moss species.

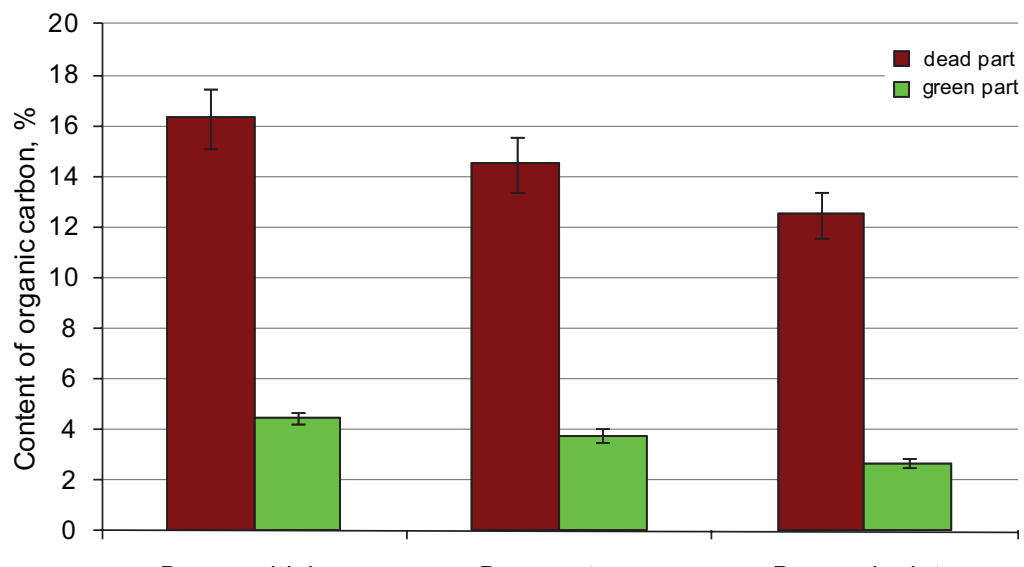

B. caespiticium

B. argenteum

B. unguiculata

Fig. 3. Content of the organic carbon in green and dead shoot parts of mosses

Рис. 3. Вміст органічного вуглецю у зеленій і відмерлій частині пагонів мохів

We established a direct dependence between bedding thickness and the content of organic carbon in the substrate under vegetable cover in natural moss samples. Maximum content of the organic carbon in the substrate under moss cover was determined on the dump crest (3.4-4.7\%). On the north slope, the highest content of organic carbon was in the substrate under mosses Bryum caespiticium and Bryum argenteum, that is almost 1.6 times higher compared to the carbon quantity in bare substrate from this dump plot (Table 1). The carbon quantity was 1.4 times higher under the turfs Barbula unguiculata compared to its content in the substrate without turfs. Similar tendency of the organic carbon content change in the substrate under investigated moss species has been also observed in the slope base.

The smallest quantity of the organic carbon under the moss turfs has been found on the top, although comparing to its quantity in bare substrate on this dump plot, its content increased almost 1.7-2.0 times, that shows an essential bryophyte contribution in accumulation of the organic substances even under the unfavourable ecological conditions. The results of determining a content of the organic carbon in the substrate under moss cover on the south dump No 1 slope show the similar conformity: the highest content was found in the substrate under mosses on the slope and in the dump base, and the lowest content was found on the top. On the basis of the obtained results, one can confirm that the process of soil formation occurs with the bryophyte participation on the dump territory.

It is known that the increase of organic carbon content in the technogenic substrates taken place until its losses, as a result of mineralization and washing out processes do not become equal with the entrance of the organic substance to soil block of the ecosystems as dead organic remnants. According to the data of many investigators this process can last from 20 to 50 years. Then it continues mainly at the expense of 
qualitative transformations of the organic substance. Thus, the total regularity of the processes of organic substance accumulation is the following: relatively rapid accumulation of the organic carbon at the initial period of young soil ontogenesis and the following slowing down of humus accumulation rates with the change of components correlation of organic substance [5].

The results of two year analysis of the organic carbon content in not populated substrate and the substrate under turfs of investigated mosses show positive dynamics of its increase in all investigated transects, but the rate of the organic carbon accumulation in upper horizons of the posttechnogenic substrate on the dump territory is different, it depends on the microrelief, microclimatic conditions, projective bryophytes covering and their species composition (Table 1).

On the basis of the organic carbon content analysis in 2015 it was established that carbon content within the investigated plots is increased by $0.07-0.27 \% \mathrm{C}_{\text {org. }}$, in comparison with the data in 2013 (Table 1).

Changes of the organic carbon content in the uncovered substrate were not essential during this period. The highest indices of the organic carbon content in the bedding layer under moss cover have been determined on the crest and in the dump base, especially under the species Bryum caespiticium with dense turfs, accumulating organic substances. The tendency of decreasing organic carbon content has been observed in the substrate under the moss turfs from the base to the dump top of the north and south exposition.

One of the main soils characteristics determining their fertility and ability for plants population is their supply with the nutrition elements. Technogenic dump substrate of sulphur extraction is not almost structuralized, it is characterized by the insufficient absorbing and water keeping properties being poorly supplied with the main nutrition elements (nitrogen, phosphorus, potassium), that in complex defines its low potential fertility and adaptability to plants life activity [9]. It is known that bryophytes play an important role in the circulation of nutritious substances in ecosystem, in spite of relatively small part of their biomass compared to vascular plants [4; 16]. The mosses can absorb nutritious substances from the atmospheric air, precipitation, dust and keep them during long period of time in undecomposed part of dead shoots [21]. The main reasons of it are the conditions of bryophyte existence (low temperature, humidity, heightened acidity) as well as some of their physical and chemical properties (high cation exchange capacity, availability of essential content of lignin-like compounds and lipids) [6].

The bryophyte role in accumulation of nitrogen in soil is estimated in numerous publications $[3 ; 5 ; 8 ; 11]$. It has been established that the dead part of moss cover has rather high hydrolytic acidity, due to this factor the moss bedding is characterized by the essential absorption ability and can contain not only hydrogen ions in great quantities, but also other elements necessary for plants [15]. In the primary succession on the sands the rate of nitrogen accumulation in moss cover, formed by Polytrichum juniperium Hedw. and Polytrichum piliferum Hedw. amounted to $10.1 \mathrm{~kg} / \mathrm{hectare} / \mathrm{year}$, $58 \%$ of accumulative nitrogen has been accumulated in moss bedding. This fact shows that bryophyte component positively influences the edaphic conditions. To confirm such assumption, the moss cover was fully removed on the essential area of the investigated territory, and it has been found out that nitrogen losses in the ecosystem essentially exceeded its entrance [4]. It has been established in arctic ecosystems that some species of Sphagnum genus as well as Hylocomium splendens (Hedw.) Schimp.

ISSN 1996-4536 (print) • ISSN 2311-0783 (on-line) • Біологічні Студії / Studia Biologica • 2016 • Том 10/№3-4 • С. 71-82 
and Pleurozium schreberi (Willd. ex Brid.) Mitt. accumulate three times as much nitrogen and phosphorus than Picea mariana (Mill.) Britton, Sterns \& Poggenb. [6].

We have established that mosses also influence accumulation of nitrogen and phosphorus in the substrate on the dump territory of sulphur extraction. The highest indices of their content have been determined in the substrate under mosses Bryum caespiticium and Bryum argenteum. In the substrate under moss cover formed by dense turf species Bryum caespiticium the gross nitrogen content has increased 2.0 3.0 times, phosphorus content has increased 1.2-1.4 times compared to their quantity in bare substrate (Table 2).

Table 2. Gross nitrogen, phosphorus and potassium content under moss cover on the territory of dump No 1

Таблиця 2. Валовий уміст азоту, фосфору та калію у субстраті під моховим покривом на території відвалу № 1

\begin{tabular}{|c|c|c|c|}
\hline $\begin{array}{l}\text { Locality of substrate } \\
\text { samples collection under } \\
\text { moss turfs }\end{array}$ & $\begin{array}{l}\text { Content of } \\
\text { nitrogen, \% }\end{array}$ & $\begin{array}{c}\text { Content of } \\
\text { phosphorus, \% }\end{array}$ & Content of potassium, $\%$ \\
\hline \multicolumn{4}{|c|}{ Uncovered substrate (control) } \\
\hline Crest of the dump & $0.12 \pm 0.01$ & $0.11 \pm 0.01$ & $1.77 \pm 0.01$ \\
\hline North slope & $0.11 \pm 0.01$ & $0.10 \pm 0.01$ & $1.75 \pm 0.02$ \\
\hline South slope & $0.09 \pm 0.01$ & $0.09 \pm 0.01$ & $1.74 \pm 0.03$ \\
\hline \multicolumn{4}{|c|}{ Bryum caespiticium } \\
\hline Crest of the dump & $0.39 \pm 0.02^{*}$ & $0.16 \pm 0.01^{*}$ & $1.85 \pm 0.01^{*}$ \\
\hline North slope & $0.28 \pm 0.02^{*}$ & $0.14 \pm 0.01^{*}$ & $1.86 \pm 0.01^{*}$ \\
\hline South slope & $0.20 \pm 0.02^{*}$ & $0.12 \pm 0.01$ & $1.77 \pm 0.02$ \\
\hline \multicolumn{4}{|c|}{ Bryum argenteum } \\
\hline Crest of the dump & $0.24 \pm 0.02^{*}$ & $0.14 \pm 0.01^{*}$ & $1.82 \pm 0.02$ \\
\hline North slope & $0.24 \pm 0.02^{*}$ & $0.14 \pm 0.01^{*}$ & $1.79 \pm 0.01$ \\
\hline South slope & $0.22 \pm 0.02^{*}$ & $0.11 \pm 0.01$ & $1.76 \pm 0.01$ \\
\hline \multicolumn{4}{|c|}{ Barbula unguiculata } \\
\hline Crest of the dump & $0.22 \pm 0.02^{*}$ & $0.13 \pm 0.01$ & $1.84 \pm 0.01^{*}$ \\
\hline North slope & $0.18 \pm 0.02^{*}$ & $0.13 \pm 0.01$ & $1.83 \pm 0.01^{*}$ \\
\hline South slope & $0.16 \pm 0.01^{*}$ & $0.12 \pm 0.01$ & $1.77 \pm 0.02$ \\
\hline \multicolumn{4}{|c|}{ *- difference compared to control (uncovered substrate) is statistically reliable at $p<0.05$} \\
\hline Примітка: - різниця порів & \multicolumn{3}{|c|}{ * - різниця порівняно з контролем (оголений субстрат) статистично достовірна при p<0,05 } \\
\hline \multicolumn{4}{|c|}{$\begin{array}{l}\text { The microclimatic conditions on the dump territory also influence accumulation of } \\
\text { nitrogen and phosphorus in the substrate, as the highest content of these elements was } \\
\text { determined in the substrate on the dump crest. The lowest content was on the south } \\
\text { dump slope, thus, the dependence on the conditions of plant localities is observed. } \\
\text { Perhaps, the high insolation level on the south dump slope influences these indices as }\end{array}$} \\
\hline
\end{tabular}

ISSN 1996-4536 (print) • ISSN 2311-0783 (on-line) • Біологічні Студії / Studia Biologica • 2016 • Том 10/№3-4 • С. 71-82 
for many moss species negative correlation between nitrogen and phosphorus accumulation and light intensity has been established [6].

The mosses role in potassium accumulation in the upper mineral ground horizon has been shown in numerans publications [8; 19]. These investigations deal mainly with mosses which get used to the life in the forest cenoses (species of the genus Sphagnum, Pleurozium shreberi, Dicranum polysetum Sw.). The analysis of potassium content in the dump substrate has not shown the essential differences between its quantity in bare substrate and in substrate under the bryophyte cover. Perhaps, the reason of this is in specific properties or specific character of ions in moss shoots, as it was established that univalent cations (for all $\mathrm{K}^{+}$) are most of all concentrated in the shoot apex, but divalent cations are located in the basal old part [6]. In our experiments, a reliable increase in potassium content in the substrate has been fixed on the crest and the north dump slope only under moss turfs Bryum caespiticium and Barbula unguiculata.

Taking into account that the moss turfs overgrow and are concentrated in the upper layer $0-3 \mathrm{~cm}$ of the soil substrate, it is natural that almost all organic substances being a potential source of humus at the initial stage of soil formation are concentrated on the surface or in soil of $0-3 \mathrm{~cm}$ thickness, where the process of their mineralization and humus formation take place.

A high variability of the organic substance content is determined by both specific moss peculiarities and the microconditions on the dump territory. The lowest indices of the organic carbon content have been determined on the dump top that may be caused by both tension of the ecological factors on this plot (high insolation level, moisture deficit), and the periodic transference of the upper horizons of soil formation substrate down the slope, as the result of the morphodynamic processes that are characteristic for the technogenic landscapes.

The rate of the organic carbon accumulation in the upper horizons of posttechnogenic soil on the dump territory is different, and it depends on the microrelief, microclimatic conditions, projective bryophytes covering, and their species composition. On the basis monitoring of the organic carbon content during 2013-2015 years, the accumulation rates of carbon within the investigated plots amounted to be $0.03-0.13 \% \mathrm{C}_{\text {org. }}$ per year. Changes in the organic carbon content in the uncovered substrate were not essential during this period. The highest indices of the organic carbon content in the bedding layer under the moss cover have been determined on the crest and in the dump base, especially under Bryum caespiticium species with dense turfs, accumulating the organic substances. A tendency of decreasing the organic carbon content has been observed in the substrate under the moss turfs from the base to the dump top of the north and south exposition.

It is obvious that essential changeability of organic carbon accumulation rate can be caused by the fact that an essential part of the organic substance on the dump territory is represented by the un-decomposed organic remnants (mainly by the decay products of moss turfs and by the introduced falling of the vascular plants). This can point to slow mineralization of plant remnants as a result of specific hydrological conditions and unripeness of microorganism groups being the main destructors of the organic remnants [9].

Thus, it has been established that the bryophytes promote an enrichment of the dump substrate with the biogenic elements. The life form of mosses has an essential influence on the process since the highest indices of the organic carbon, nitrogen and

ISSN 1996-4536 (print) • ISSN 2311-0783 (on-line) • Біологічні Студії / Studia Biologica • 2016 • Том 10/№3-4 • С. 71-82 
phosphorus content were fixed in a substrate under the moss Bryum caespiticium with the dense turfs. The important role is also played by specific ecological conditions on the slopes of the dump.

At the early stages of soil formation, the bryophytes as pioneer plants play an important role in this process promoting accumulation of the organic substance and, in that way creating the conditions for the development of other higher plants and soil biota.

\section{CONCLUSION}

Bryophyte cover provides the formation of humus horizons on a surface of the technogenic substrates. That is connected with the character of dump substrate population by the moss turfs which form the whole dense cover on the surface of dump substrate. Colonizing technogenic exfoliation bryophytes perform complex action on the dump substrate, namely:

- They initiate the processes of the upper horizons structuring under the moss cover technogenic soil is loosened, and acquires a coarse lumplike structure, its porosity increases that promotes substrate enrichment with oxygen and moisture.

- On the slopes, mosses fix movable substrate mechanically and prevent scattering of its light particles.

- Mosses accumulate the organic substance.

1. Agrochemical methods of the soil investigations. Ed. A.V. Cokolov. M.: Nauka, 1975. 656 p. (In Russian).

2. Arinushkina E.V. Guide for chemical analysis of soils. M.: Nauka, 1970. 488 p. (In Russian).

3. Bowden R.D. Input, outputs and accumulation of nitrogen in an early successional moss (Polytrichum) ecosystem. Ecological Monographs, 2009; 61: 207-214.

4. Bowden W.B., Arscott D., Pappathanasi D. et al. Roles of bryophytes in stream ecosystems. J. N. Amer. Benthol. Soc, 2010; 18: 151-184.

5. Brisbee K.E., Gower S.T., Norman J.M. et al. Environmental control on ground cover species composition and productivity in a boreal black spruce forest. Oecologia, 2010; 129: 261270.

6. Goffinet B., Shaw A.J. Bryophyte Biology. $2^{\text {nd }}$ Ed. New York: Cambridge University Press, 2012. $565 \mathrm{p}$.

7. Lisetskiy F.N., Goleusov P.V., Kuharuk N.S. et al. Ecological aspects of reproduction of the soil-vegetative cover in the landscapes broken by the mining industry. On-line Scientific Journal "Investigated in Russia". http://zhurnal.ape.relarn.ru/articles/2005/217.pdf. (12.05.2012) (In Russian).

8. Longton R.E. The role of bryophytes and lichens in terrestrial ecosystems. In: J.W. Bates and A.M. Farmer (Eds.) Bryophytes and Lichens in a Changing Environment. Oxford: Clarendon Press, 1992: 32-76.

9. Maryskevych O.H. Formation of soil within the technogenic landscape of Novoyavorivsk State Mining-Chemical Enterprise "Sirka". Scientific Bulletin of Chernivtsi University. Biologycal Series, 2005; 251: 175-185. (In Ukrainian).

10. Mineev V.G. Workshop on Agricultural Chemistry. M.: Moscow University Press, 1989; $304 \mathrm{p}$.

11. Möls T., Vellak K., Vellak A. et al. Global gradients in moss and vascular plant diversity. Biodiversity and Conservation, 2013; 22: 1537-1551.

12. O'Neill K.P. Bryophytes in the global carbon budget. In: A.J. Shaw, B. Goffinet. (Eds.) Bryophyte Biology. Oxford: Clarendon Press, 2000: 344-368.

13. Plochinsky N.A. Biometry. M.: Moscow Univ. Publ., 1970: 367 p. (In Russian).

ISSN 1996-4536 (print) • ISSN 2311-0783 (on-line) • Біологічні Студії / Studia Biologica • 2016 • Том 10/№3-4 • С. 71-82 
14. Rabyk I., Danylkiv I., Shcherbachenko O. The structure and dynamics of bryophytes communities on devastated territories of Lviv region (mining-chemical enterprise "Sulfur"). Bulletin of Lviv University. Biological Series. 2010; 53: 58-66 (In Ukrainian).

15. Ringen $D$. The role of moss in facilitating natural revegetation of metal-contaminating sites during primary succession. www.bioed.org/ibscore/ (22.06.2013).

16. Sanger J.C., Kirkpatrick J.B. Moss and vascular epiphyte distributions over host tree and elevation gradients in Australian subtropical rainforest. Australian Journal of Botany. 2015; 63(8): 696-704.

17. Sheng-Bin Chen, Ferry Slik J.W., Jie Gao et al. Latitudinal diversity gradients in bryophytes and woody plants: Roles of temperature and water availability. Journal of Systematics and Evolution, 2015; 99(3): 1-15.

18. Świercz A. Rola biowskaźników w monitoringu zanieczyszczeń środowiska i rekultywacji terenów poprzemysłowych. In: M. Strzyż (Ed.) Perspektywy rozwoju regionu w świetle badań krajobrazowych. Kielce, 2004. S. 235-241.

19. Świercz $A$. Chemical transformations of podzolic soils induced by alkaline and acidic emissions in the Świętokrzyski region of Poland. Polish J. of Environ. Stud. 2008; 17(1): 129-138.

20. Trofimets V.I., Ipatov V.S. The role of lichens and moss cover in the dry pine forest. Bot. Journ, 1990; 75 (8): 1102-1109.

21. Tuba Z., Slack N.G., Stark L.R. Bryophyte Ecology and Climate Change. New York: Cambridge University Press, 2013. 505 p.

\title{
РОЛЬ БРІОФІТНОГО ПОКРИВУ В НАГРОМАДЖЕННІ ОРГАНІЧНОГО КАРБОНУ ТА БІОГЕННИХ ЕЛЕМЕНТІВ У ТЕХНОГЕННОМУ СУБСТРАТІ НА ДЕВАСТОВАНИХ ТЕРИТОРІЯХ ВИДОБУТКУ СІРКИ
}

\author{
Н. Я. Кияк, О. Л. Баїк
}

Інститут еколоаії Карпат НАН України, вул. Стефраника, 11, Львів 79000, Україна e-mail:kyyak_n@i.ua

Досліджено вплив бріофітного покриву на нагромадження органічного карбону та біогенних елементів у субстраті відвалу № 1 Язівського сірчаного родовища Новояворівського державного гірничо-хімічного підприємства “Сірка" (Львівська обл., Яворівський р-н). Мохоподібні одними з перших оселилися на субстратах відвалів і сорормували рясні багатовидові угруповання. 3'ясовано, що вміст органічного карбону в субстраті під дернинами мохів збільшувався в 1,6-1,8 разу, порівняно з його вмістом у незадернованому субстраті. Найнижчі показники вмісту органічного вуглецю визначені на вершині відвалу, що може бути зумовлено напруженістю екологічних фракторів на цій ділянці (високий рівень інсоляції, дефіцит вологи). Виявлено, що мохоподібні сприяють збагаченню субстрату відвалу біогенними елементами, насамперед азотом і фосфором. Висока варіабельність вмісту органічної речовини детермінована як видовими особливостями мохів, так і мікрокліматичними умовами на території відвалу. Важливе значення має життєва фрорма видів, оскільки найвищі показники вмісту органічного карбону, азоту й фосфору визначені під моховим покривом, сфрормованим щільнодернинним видом Bryum caespiticium. Отже, бріофіти як піонерні рослини відіграють важливу роль у процесі відновлення техногенних субстратів, сприяючи накопиченню органічної речовини й, тим самим, створюючи умови для розвитку інших вищих рослин і ґрунтової біоти.

Ключові слова: бріофіти, органічний карбон, біогенні елементи, відвал сірчаного видобутку.

ISSN 1996-4536 (print) •ISSN 2311-0783 (on-line) • Біологічні Студії / Studia Biologica • 2016 • Том 10/№3-4 • C. 71-82 


\section{РОЛЬ БРИОФИТНОГО ПОКРОВА В НАКОПЛЕНИИ ОРГАНИЧЕСКОГО КАРБОНА И БИОГЕННЫХ ЭЛЕМЕНТОВ В ТЕХНОГЕННОМ СУБСТРАТЕ НА ДЕВАСТИРОВАННЫХ ТЕРРИТОРИЯХ ДОБЫЧИ СЕРЫ}

Н. Я. Кияк, О.Л. Баик

Институт экологии Карпат НАН Украины, ул. Стефраныка, 11, Львов 79000, Украина e-mail:kyyak_n@i.ua

Исследовано влияние бриофитного покрова на накопление органического карбона и биогенных элементов в субстрате отвала №1 Язовского месторождения серы Новояворовского государственного горно-химического предприятия «Сера» (Львовская обл., Яворовский р-н). Мохообразные являются пионерными растениями на субстратах отвалов, которые сформировали обильные многовидовые сообщества. Показано, что содержание органического карбона в субстрате под дерновинами мхов увеличивалось в 1,6-1,8 раза по сравнению с его количеством в субстрате без растительного покрова. Наиболее низкие показатели содержания органического карбона определены на вершине отвала, что обусловлено напряженностью экологических факторов на этом участке (высокий уровень инсоляции, дефицит влаги). Выявлено, что мохообразные способствуют обогащению субстрата отвала биогенными элементами, прежде всего азотом и фоссрором. Высокая вариабельность содержания органического вещества детерминирована как видовыми особенностями мхов, так и микроклиматическими условиями на территории отвала. Важное значение имеет жизненная форма видов, поскольку высокие показатели содержания органического карбона, азота и фосфрора определены под моховым покровом, сформированном плотнодерновинным видом Bryum caespiticium. Таким образом, бриофиты как пионерные растения играют важную роль в процессе восстановления техногенных субстратов, способствуя накоплению органического вещества и, тем самым, создавая условия для развития других высших растений и почвенной биоты.

Ключевые слова: бриофиты, органический карбон, биогенные элементы, отвал добычи серы.

Одержано: 26.10.2016

ISSN 1996-4536 (print) •ISSN 2311-0783 (on-line) • Біологічні Студії / Studia Biologica • 2016 • Том 10/№3-4 • C. 71-82 